\title{
Recognizing Typology in Historical Native American Leadership: Implications for Contemporary Praxes
}

\author{
Robb Elton1, Amy Moore ${ }^{2}$ \\ ${ }^{1}$ School of Business, Northcentral University, La Jolla, CA, USA \\ ${ }^{2}$ Navy Administrative Contractor, King George, VA, USA \\ Email: r.elton3368@o365.ncu.edu, amoore@teamscci.com
}

How to cite this paper: Elton, R., \& Moore, A. (2021). Recognizing Typology in Historical Native American Leadership: Implications for Contemporary Praxes. Open Journal of Leadership, 10, 257-276.

https://doi.org/10.4236/oj1.2021.104017

Received: September 13, 2021

Accepted: November 8, 2021

Published: November 11, 2021

Copyright (c) 2021 by author(s) and Scientific Research Publishing Inc. This work is licensed under the Creative Commons Attribution International License (CC BY 4.0).

http://creativecommons.org/licenses/by/4.0/ (c) (i) Open Access

\begin{abstract}
The various forms of damage, to include genocide that historic colonialism has instituted upon Native American people, are no longer a secret. Native Americans have suffered through many negative socio-psychological effects through this process. Despite their historical maltreatment, Native Americans have proven resilient. The authors hypothesized that specific traits have been prominent in the histories of Native American leaders although they mostly came from distinct tribal systems. What does this type of leadership look like? To engage the hypothesis, we used Boolean operator search functions which helped refine keywords in searches. We then used computer-aided random selection for data with which to analyze leadership behavior of four Indigenous leaders. These leaders $(n=50)$ were drawn from a historic pool of people, from four separate databases. Through surveying the literature, it became necessary to conduct extensive case studies of select leaders. We detailed various leadership traits exhibited by a randomly selected Native American population (5-percent) and were able to synthesize and classify the results in a word cloud as either innate or cognate characteristics. While these leaders were separated by time, tribe, and vast geographical distance-in an area that became the United States-their traits, when integrated, revealed a thematic framework of Native American leadership-a typology that could inform and guide leaders (and managers) in various contemporary praxes.
\end{abstract}

\section{Keywords}

Indigenous Leadership, Decision-Making, Native American Leadership, Native Studies, Indigenous History 


\section{Introduction}

According to some contemporary experts, leadership is viewed as implicating completion of tasks and work, with and through people, and it implicates respect, assurance, compliance, and cooperation (Greer \& Plunkett, 2007; Kjellström et al., 2020). A separate international example described leadership and management as pessimistically distinct and in the following sentence claimed the root of leadership was trait-based, before itemizing a litany of desirable qualities to establish leadership as superior to management (Koshhal \& Guraya, 2016). This argument was not taken up here; however, it was important for epistemological purposes to mention this notion has been proposed in current literature. On the contrary, other experts have even espoused that scientific evidence did not exist to argue any "described differences between leadership and management; what remains is an abstraction of two concepts with no consensus and little application" (Azad et al., 2017). Both perspectives-despite philosophical distinctions-insist upon great leaders and managers having a broad cache of skills and traits that depict somewhat overlapping forms. There is no consensus definition of leadership, and most conceptual models are overly complex. Leaders from various cultures take on unique forms influenced by situational or geographical settings. For the Indigenous of America, survival leadership has been part of their heritage. This is considering that since 1492, tribes have been forced into existential-level decisions. Leadership had to clearly reflect and represent the entirety of a tribe. Gender was not a barrier to leadership in most cases, but the people typically determined their own leadership for tasks and government.

In movies and other popular media, Indigenous American leaders are romanticized-as often Sioux-Indian males-sitting around a "nighttime fire (depicting the inside of a teepee) bickering about issues, and perhaps passing a pipe while a drum beats into the night" (bigorrin.org, 2021). On the contrary, most American Indigenous leadership held council in vastly diverse areas and places, even representing matriarchal societies; considering the matriarchal and matrilineal discourse regarding former tribes of the east coast of the United States: the Cherokee in Carney (2001), and Choctaw from McGowan (2001). Literature also exists relating to the Pueblos, who live thousands of miles from the aboriginal homes of the Cherokee and Choctaw, as a tribe from southwestern United States (Allen, 1986).

The Caddo tribe's aboriginal homeland ranged from the Red River border between what are now states of Oklahoma and Texas, and to Louisiana, up to Arkansas (National Park Service, 2021). Caddo tribal leadership met in grass structures; the Iroquois are named for their structures of meeting: "People of the Longhouses" (Kannonsionni), a confederacy of The Six Nations, or Haudenosaunee (Reedy et al., 2020). These six distinct nations include the Seneca, Cayuga, Oneida, Mohawk, and Onandaga and later, the Tuscarora. Today, this Six Nation Council is known as the Iroquois League. Each of The Six Nations has representative leadership who are selected by the clan mothers of each Nation. These fifty-six chieftain leaders (Hoyenah) make up The Great Iroquois Council 
(bigorrin.org, 2021). This ancient council is nearly six-hundred-years old. According to the best contemporary archaeological evidence, it is stated to have begun around the year 1450 C.E. (2021).

Throughout half a millennia, the clan mother's of the Six Nations have made their selected Hoyenah to the Great Council. Historically, there were undoubtedly difficult decisions made by these elected Hoyenah as they were one of the first peoples to encounter colonists from England. More difficult still, was that courses of action taken by the council had to be unanimous (2021). The Sioux councils also acted "in unison," according to Clow (1998). Seemingly, various Native people have similar ideals and characteristics as uncovered herein (Harris \& Wasilewski, 2004).

\subsection{Background in Leadership}

To be considered as a leader, whether having adopted the moniker or not, requires elaboration, from which consensus regarding one's leadership emerges. The opinions of one's competition also contribute to this title: leader. This brings into the discourse a rudimentary connection to thematic styles of leadership: transformative leadership, democratic leadership, laissez-faire, and autocratic forms. Additionally, leadership style is stated to emerge in situational contexts, such as suggested in The Goleman Six leadership styles. These are: commanding, visionary, democratic, coaching, affiliative, and pace-setting (Goleman, Boyatzis, \& McKee, 2002). Paired with emotional intelligence, these six traits, as commonly defined, were stated without scientific bases to be superior to Lewin's style (Goleman, Boyatzis, \& McKee, 2002).

For the most part, leadership styles share more similarities than distinctions. As Lewin created his work, World War II was in full swing (Lewin \& Lewin, 1948). When Goleman crafted his, the 11 September 2001 attacks were fresh in the world's consciousness, and the United States went to war in Iraq. While leadership styles were not targeted in this paper, these facts were worth mention considering the historically hefty reliance upon trait-based theories in leadership studies, and that their development coincided with war. This idea seems to be true for depictions of Native American leadership-most of the historical leaders commonly appear in texts, archives, and records as war chieftains and military officials. An online encyclopedia lists thirty-six matching this criterion (Wikipedia, 2021a). Native leaders recognized for diplomatic skill were Sacagawea (a Shoshone translator, healer, guide for the Lewis and Clark Expedition), Wilma Mankiller (female Cherokee Chief), and Sequoyah (a Cherokee, who created a syllabary for his tribe), and recently, Deb Halaand (Laguna Pueblo), the first Native to head a cabinet-level office as Secretary of Interior, and healers (Gambrel \& Fritz, 2012).

Notably, within the past fourteen-years there has been subtle, consistent publishing invoking aspects of Native American leadership, albeit in the form of doctoral dissertations (see Munson, 2007; Alanis, 2020). Leadership in some areas that focus on "the work of actors outside the governmental ... sphere of research 
and analysis ... has been ignored" (Jimenez-Luque, 2020). The available scholarship cited in this paragraph focused on modern situational factors such as, casino management, entrepreneurship, health care, or forms of administration. Beckstein (2021) provided a comprehensive overview of Native American leadership, while this inquiry attempts to add to the sparse conversation of Native American leadership studies. Included herein is a typology that developed from a historically broad and practical leadership lineage. The typology is further expounded upon in a way that could add relevance and applicability for many contemporary contexts. Indeed contemporary research on practice in Native leadership is encouraged and needed (Freeman et al., 2019). These are promising words for emerging scholars and stakeholders within Indigenous communities; especially so, understanding the many ways Native American studies has hitherto been misunderstood, abused, and its diverse messages, perspectives, or views have been lost behind the dominant western paradigms, or arguably worse: commoditized (Anthers, 2008).

For example, a non-Indian researcher once reported in his study of a Native community that he heard a "person state that they would not speak about leadership" on another's behalf (Bryant, 1996). Referring to the inconspicuouseven regional-diversity of Indigenous viewpoints this Native interviewee confounded Bryant, who viewed such an idea-a culturally sensitive Native not talking in the place of others-as inherently antagonistic to his qualitative approach. This disapproval came in addition to two obvious faux pas, one of which, he inadvertently emphasized within the title of his paper-despite his well-meaning attempts at respect (Bryant, 1996). Perhaps research of Indigenous people has evolved since the nineties (Walden \& West, 2019).

\subsection{Purpose}

The literature reinforces the notion that leaders possess a specific set of traits; this idea also traverses cultures. Operating under this assumption our purpose was to look through the lens of Native American history to learn what exactly constituted a leader, that is, how leadership or leaders were defined and distinguished. Our hypothesis: there is a common set of traits representing an underlying form or structure. The literature is lacking in this area. In conducting the case studies, we agreed to ignore whether one was diplomatic or involved in direct warfare, as leadership can manifest in various roles, such as individually or leadership via election-how leaders were chosen in historical Native American government.

However, leadership regarding history of Native Americans only goes back so far-due to their general oral traditions, and also, that not much by way of archival data has survived time, nor the onset of colonial destruction. There does exist of plethora of sources in books, articles, and biographical information regarding the people surveyed for common elements of leadership. Undertaking this thematic analysis we imagined some form would emerge. We further consi- 
dered traits distinguishable as either innate or cognate concepts-intrinsic notions ever-present, or extrinsic one's that can be tapped to magnify leadership.

Indigenous methodologies and research traditions are currently-more than any time in the past-considered knowable, researchable, and important forms of knowledge (Hanson, 2012). We used thematic analysis of biographies and cross-referenced where possible. This approach is supported in literature. Indigenous American communities, and Indigenous people abroad, share similarities in valued oral traditions, ethnography, and case studies over other Western dominated forms of research and knowledge gathering (Chilisa, 2019). Indigenous academics-though non-Indians have-this century-been able to impart frameworks, paradigms of Indigenous research and knowledge bases, reliable forms of epistemological production, and ways social science researchers can meaningfully engage with these (Chilisa, 2019; Cooper, 1988).

\section{Methodology}

Sampling every Native American in history for leadership qualities would be unreasonable. There needed to be a workable sample of individuals and groups to analyze for whatever traits or characteristics could be uncovered. A potential population of eighty leaders $(n=80)$ systematically sampled from four random databases permitted sufficient saturation. Terms such as "Great leaders of Native America," "Native American or Indian, leader or Chief," and "Indian Leaders or chiefs" including combinations thereof-using Boolean operators in searchesrefined millions of journal articles and books via Northcentral University library. Boolean operators are connecting terms such as, AND, OR, NOT which acts as delimiters in most databases (Lowe, Maxson, Stone, Miller, Snajdr, \& Hanna, 2018). This established a primary list. Three other non-Boolean searches via Google, using the same terms were also conducted. Twenty names from each of the next three databases (Google, historynet.com (2021), and U-s-history.com (2021)) provided the other sixty non-ordered or ranked individuals which were compared to the first twenty-names derived from the initial Boolean-operatorproduced list $(n=80)$. U-s-history.com did have data categorized by century, 1500-1900s. It was unknown why the 2000s were absent from their data. The names were ranked by number of appearances from any previous list. These were incorporated in this research, refining a core of eighty potential leaders to a population of fifty that had the most impact by searches. Names listed in the Appendix.

Once the core population of the ranked leaders were established $(n=50)$ the number of times they appeared in any list was noted beside their names. The leaders who were listed more than once, totaled twenty-two ( $44 \%$ of 50 ). To establish use of the strongest half of the leadership population could be chosen we needed three additional random names. The authors randomly asked two people to pick a number between 1 and 28 . These numbers established the final three names and established the refined potential study population of twenty-five ( $n=$ 
25): exactly half of the population. Table 1 enumerates these findings. We realized that these names were biased by the search engine, but this is exactly the core of what needed to be known: what the world considered leadership.

The twenty-five most recorded leaders were placed into random name picking software. The authors chose to limit the research to a random sample of four individuals (16\%) as case studies would prove extensive. From this process, four leaders/subjects emerged from the generator, archived in Table 2: Chief Joseph, Tecumseh, Spotted Tail, and Quanah Parker. Once the subjects of our case studies became known, their available histories and records were analyzed and compared. Next, leadership traits derived from their case studies were placed into a word cloud. After, they were further categorized as either innate (inherent as part of the personality or identity), or cognate (external, environmental factors that are closely related aspects of leadership). Table 2 details itemized findings.

Table 1. Leaders appearing in searches more than once (25 of $n=50)$.

\begin{tabular}{lc}
\hline \multicolumn{1}{c}{ Individual Leaders } & Times Listed \\
\hline Cochise, Geronimo & 4 \\
Red Cloud, Tecumseh, Spotted Tail, Sitting Bull, Seattle. & 3 \\
$\begin{array}{l}\text { Chief Joseph, Mangus Coloradas, Powhatan, Blackhawk, Chief Leshi, } \\
\text { Quanah Parker, Bigfoot, Pocahontas, Sakajawea, Santana/Satanta, } \\
\text { Rain-in-the-Face, Gall, Crazy Horse, Manuelito }\end{array}$ & 2 \\
Pontiac, Red Jacket, Hiawatha, Chief Illiniwek & $1^{*}$ \\
\hline
\end{tabular}

Source: Elton \& Moore. ${ }^{\star}$ Listed once but included to use $50 \%$ of population.

Table 2. Word cloud: leadership traits as innate or cognate.

\begin{tabular}{lll}
\hline Indigenous Leader & \multicolumn{1}{c}{ Innate Traits } & \multicolumn{1}{c}{ Cognate Traits } \\
\hline Chief Joseph & $\begin{array}{l}\text { Honest, people centered, } \\
\text { spiritual, sense of timing, } \\
\text { proactive, intelligent, creative }\end{array}$ & $\begin{array}{l}\text { Broad social knowledge, used } \\
\text { councils, renowned } \\
\text { communicator, negotiator }\end{array}$ \\
\hline Tecumseh & $\begin{array}{l}\text { Honest, devoted to the people, } \\
\text { highly intelligent, intuitive, } \\
\text { creative strategist, spiritually } \\
\text { cognizant, diplomatic, visionary }\end{array}$ & $\begin{array}{l}\text { Broad social understanding, used } \\
\text { councils and created them, } \\
\text { historian, renowned } \\
\text { communicator, negotiator }\end{array}$ \\
\hline Spotted Tail & $\begin{array}{l}\text { Courageous, charitable, } \\
\text { diplomatic. Good example, } \\
\text { fortitude, wisdom; spiritual, } \\
\text { creative, bold. }\end{array}$ & $\begin{array}{l}\text { Adept negotiator, great } \\
\text { communicator, persuasive, and } \\
\text { used councils, engaged in political } \\
\text { intrigue and manipulated others }\end{array}$ \\
\hline Quanah Parker & $\begin{array}{l}\text { Courageous, man of his people, } \\
\text { fair, wise, intelligent, spiritually } \\
\text { adept, and creative, understood } \\
\text { time, diplomatic }\end{array}$ & $\begin{array}{l}\text { Great communicator in two } \\
\text { languages, persuasive, and held } \\
\text { council with an array of people }\end{array}$ \\
\hline
\end{tabular}

Source: Elton \& Moore. 


\section{Results: Case Studies and Historical Context}

Chief Joseph, or Hin- mah-too- yah- lat-kekt, was his real name; he was intelligent and progressive according to the non-Indian who coaxed Joseph into an appearance at the 1904 World's Fair (Swenson, 2019). The US newspapers- after the Indian Wars of the 1870s-labeled Joseph a military genius; however, most accurately-while he did have skirmishes with U.S. military, he is mostly known to have led a retreat. At that same time those reports depicted him as compassionate for his care of his wounded and captured. Having outwitted the United States military for five months during the wars of 1877, he was remembered as smart, creative, and even noble by many people by the dawn of the century (Swenson, 2019; Fee, 1936). However, "Joseph was a respected statesman and orator, not a war chief," and "reappraisal of this view" by Native Americans has also been documented (Guthrie, 2007; Howard, 2017). Ollokot, Joseph's brother, was someone who could have been termed a War Chief or Chief. Chief Joseph, then, only negotiated for those people who did not want to cede land via treaty (Guthrie, 2007).

As for Chief Joseph's behavior-as opposed to speeches attributed to him-we then looked to what people in his tribe thought; facts which might help if anything could be learned. Much was documented about his communication ability, creativity, and sense of timing. Indeed he was known for the deep connection to his lands and people, and he held councils when necessary with other leadership, namely, Lean Elk, Looking-Glass, White Bird, and Ollokot, even councils with the U.S. government officials. Though very little is knowable about how he behaved outside of alleged military situations (Serena, 2019). For a full anthropological perspective on Nez Pierce spirituality, custom, and practices see four volumes by Cunningham (1889-1892).

Tecumseh is legendary. As a Shawnee diplomat and Chief, was the central force in the second Indian Unity Movement, ca.1805-1813 along with his brother, the prophet, Tenskwatawa (Dowd, 1992). Tecumseh relied upon tradition and exploited established networks of intertribal relations in his own actions to thwart western expansion, even allied with the British at the end of his movement and life. There is much more history surrounding the life and actions of Tecumseh than Chief Joseph. This is not only due to his military-based interactions with multiple nations (France, England, Spain, and then, new United States, colonies) but evidenced by the strong and respected connection to William Henry Harrison.

William Henry Harrison would become the shortest sitting president in history, having died from what earlier historians thought of as having been pneumonia. However, more recent scholarship depicts that Harrison probably died of “enteric fever" (McHugh \& Mackowiak, 2014). In Harrison's time as governor of the territory of Indiana, and as a general in the Army, he would have many interactions with Tecumseh. They also communicated by letter, including the powerful spiritual exchange in 1810: "How can we have confidence in the white 
people ... when Jesus Christ came upon the earth you kill'd and nail'd him on a cross" (Harrison's Messages and Letters).

Tecumseh further expanded upon the power of belief, having coordinated with his brother, "The Prophet," to structure an intertribal unity. Fundamental to this realization was that as separate Indian Nations they could not oppose western expansion, but only together. This is exemplified in their uniting elements of the Shawnee, Winnebago, Wyandotte, many Miami, Muscogee, (Red Sticks), Cherokee, Ottawa, and Choctaw by 1811 (Dowd, 1992 citing Woodward, 1859).

Further evidence after the War of 1812 cements Tecumseh's intimate sensibilities to intertribalism and unity amongst Native peoples (Sugden, 1986). In 1813 he fought in the Creek War with the Red Sticks-an anti-colonial segment of the Muscogee Nation. The war ended at the signing of the Treaty of Fort Jackson in August 1814 (Halbert \& Ball, 1895). Tecumseh died fighting near "Thames River, Ontario, Canada on 5 October 1813" (Laxer, 2012; West, 2012). He was not doubted by his followers, though criticized by other (non-fighting) tribal leaders, at times. He is remembered as highly intelligent, intuitive, and a creative strategist who understood time, was spiritually cognizant, diplomatic, and a great communicator. Tecumseh lived, fought, and died believing in his people and felt deeply for the well-being of all Natives.

Spotted Tail, or Sinte Gleska, was Sicangu Oyate Lakota (a branch of Sioux in a modern sense) and he lived in the period between Tecumseh and Chief Joseph (1823-1881). Spotted Tail was largely unknown to the authors; however, his life and actions, including his diplomacy, are felt even today. His death spawned an important legal case that led all the way to the Supreme Court, in Ex Parte Crow Dog (1883). This consequence was later codified in 18 U.S.C. 1153, otherwise known as the Major Crimes Act (1885). He was the uncle of another famous leader, Chief Crazy Horse, though not a highly published fact. He also held council with Red Cloud, another notable leader of this period (Clow, 2019). Both of these other leaders were also listed as possible candidates for study in this research; he held great company. There is a notable legacy here, without endeavoring deep into his life, his reputation alone is vast and his influence far-reaching, and having already appeared in publications of leadership (Dockstader, 1977). As a result of the discontent in how Crow Dog was punished the "Indian way," for killing Spotted Tail, Congress was pressured into passing the Major Crimes Act, a law that permits to this day exclusive federal jurisdiction over certain crimes committed by Indians in Indian country.

Despite being from a hereditary line of chiefs, Spotted Tail was respected for his connection to his people, how he honored them, and made decisions in their behalf (Hyde, 1961). He negotiated the famed Treaty of Fort Laramie in 1868-a treaty that setout the vast lands that included the sacred Black Hills. In 1980, however, the Supreme Court heard the case United States v. Sioux Nation of Indians and upheld by $8-1$ vote, the taking of the gold-filled Black Hills in 1877 by 
the United States, violating the treaty.

He is largely documented as being courageous, charitable, and being a great communicator. $\mathrm{He}$ is also recognized as an adept negotiator and diplomat. $\mathrm{He}$ led by example, using fortitude and wisdom. Importantly, as with Tecumseh, other leaders sometimes did not share his views. In his case it led to his shooting death at the hand of Crow Dog. He was also instrumental in escorting his nephew Crazy Horse to military stockade in order to keep the peace-an escort group of which Crow Dog was also involved (Clow, 1998).

Quanah Parker was born in 1845 and lived until 1911-four-years after his home territory became part of the state of Oklahoma. He lived during the same period Chief Joseph did. Quanah was even documented in the same 1904 World's Fair as Joseph and Geronimo (Swenson, 2019). To prove he was not averse to the limelight he even played a lawman in a silent movie in 1908, called The Bank Robbery. He died as Principal Chief of the Comanche, but from his birth, one would not assume he would have ever become chief.

In 1936, a little girl named Cynthia Anne Parker, aged nine, and her brother, were taken hostage by a Comanche party (Cash \& Wolff, 1974). The party killed her parents and others nearby. She ended up living as a Comanche for twenty-five years, married Chief Peta Necona, and gave birth to his three children: only Quanah survived (Carlson \& Crum, 2009; Carlson, Cram, \& Murray, 2010).

As a young man, Quanah submitted his nine-pony offering to marry his childhood sweetheart. By extending a gift of twenty ponies his friend tried to edge him out. Having none of this, Quanah and the girl left together and began a life. This of course violated tradition. However, much about Quanah violated tradition: he was half-white, he leaned to the lifestyles of the whites, yet excelled in Comanche ways. He fought against the United States until 2 June 1875 when he surrendered at Fort Sill (Norman Transcript, 2007). A few days before, he did counsel his people to lay down their arms and take up the white ways before they were all killed off.

He led the assimilation of the Comanche and is considered just like the other case studies as diplomatic, courageous, strategic, and highly intelligent. He was a great communicator, bilingual, and was considered a friend to Teddy Roosevelt, even riding in his inauguration (Moses, 1996; Binkovitz, 2013). He helped secure legislation regarding Peyote use in religious practices of his people and for other Indians tied to the Native American Church. He had seven-wives and twenty-four children. He died a wealthy man, having been a rancher, farmer, and major stockholder in various railroad companies (Leahy, 2005-2006).

\section{Discussion}

The discoveries from the four case studies took us through the history of the United States, particularly the expansion period. What we discovered was a common legacy of leadership, and expressed through many forms: war, diplomacy, and advocacy. These four leaders were from distinct groups, geography, 
and periods in history. Some of their issues overlapped. Tecumseh was the exception, a man who died free. Each seemed to share salient leadership qualities as in from the word cloud (Table 2).

A pair of things stood out, largely as a result of the advent of the reservation system and the death of the traditional ways of Native life. In the case studies of Quanah and Spotted Tail, it seemed that a separation from the customary values of their communities did occur. These situations are understandable and did not affect the traits of leadership they held while in their original environments. Their change toward money, business, and power can be seen as a symptom of transition. This is not a justification, but a subjective analysis to be noted. Considering the foundations of leadership were sought in this research and not how leaders fall from grace, this did not affect the study.

For Quanah, history dealt him with a wholly unique set of circumstances. He was mixed-blooded, and through tragedy (Gelo, 1998) Some, thought his mixedbloodedness carried weight with white society. He lived at the cusp of industrialization. While he was involved in affairs of state and commingled with the president himself, Quannah always preferred to be home nearest his people, whether they disagreed with his approach, vision, or not. The assimilation period had begun; too late to fight the inevitable, he reasoned, so he stopped fighting.

When the authors pointed out that Spotted Tail lived between the time of Tecumseh and Chief Joseph, this could also mean psychologically, along a historical spectrum of ideology created by colonial policies over Native people. Tecumseh lived during the expansion-removal period; Spotted Tail, during the Indian Wars and extermination period, also in the beginning of reservation period. Chief Joseph, lived during the reservation period and also the Indian Wars. Though being from the farthest west, in Washington and Idaho, he was one of the last to resist. Each of their eras presented different psychological obstacles and effects that influenced their leadership. With Spotted Tail, his final few years of life were replete with disagreement, evident greed, political intrigue, and unilateral decision-making. He authorized the extradition of Lakota children, including his own, to the infamous Carlisle Industrial School in Pennsylvania, the effects of which are still felt today. He also began taking women who were already married. On the reservation he lived in proximity to a government official (the Indian Agent) with whom he, Crow Dog, and others sought favor and prestige from. Being confined to a reservation-in complete antagonism to Lakota tradition-corrupted him later in life. When Spotted Tail was a true leader, he was great; when he and his people were confined to a reservation he helped negotiate, it changed his behavior. In some strange way, his death is symbolic of the diminishing importance of tribal self-government in reservations, in the passing of the Major Crimes Act. He is very prominent in history and worthy of his place.

While all cultures do not share a universal idea of what every leader looks like, 
or acts like, there is a set of universal traits that all leaders do have. Five-things can be universally agreed upon: Leadership is a consequence of persistent, complex, and formal-informal interactions, whether psychological or social. Leadership remains a social necessity; leaders can develop; leadership is based on obviated integrity. There are internal and external qualities a leader must be aware of and used as needed. To build a further mastery of these things through education, and alignment of the self with organizational vision and mission remains a contemporary responsibility for leaders in any group.

Existential-level circumstances: wars, genocide, and assimilation, were demanded of the unprepared psychology of Native American leadership since 1492. It came at no surprise that much of the Indigenous American leadership were couched as generals and termed brave and fierce, as opposed to peaceful adjectives (Gambrel \& Fritz, 2012). What can be derived from history is that leadership existed in many other tribes and people prior to colonization (Gambrel \& Fritz, 2012). This historical inquiry into the lives and behavior of these four individual leaders exposed a typology of leadership.

\subsection{Typology}

A typology is a form of classification. Typologies classify kinds of "practice that distils complex data in our case ... through the identification of key parts or categories" (Nind \& Lewthwaite, 2020). Typologies have also been used to clarify global leadership qualities and traits (Rilke et al., 2017).

The Innate-Cognate Leadership Typology is derived from the word cloud as actionable traits: innate characteristics of the Native self, which, depending upon the demand or situation, maintains the capacity to tap into the Cognate Domains. Cognate Domains are those that lie outside of oneself, yet are interrelated social aspects (see Table 2).

From analyzing the communal nature of Native American characteristics through time, across many tribal struggles, various innate traits of leadership consist of a constant tripartite theme. These concepts are not so complex. However, to describe effective function of the Innate-Cognate Typology, the concepts are elaborated upon in the following section.

\subsection{Implications for Contemporary Praxes}

Leaders are viewed as inherently trustworthy, and concerned for others. Honesty is usually considered universal by people to simply be part of leadership (Rainer et al., 2018). However, most important is the reasoning why this is so. Leaders uphold an ethical reputation, one of integrity, are less likely to be engaged in risky ventures, cheat, or conduct affairs that could place others in danger. Trustworthiness of a person, concerning one's judgment, is the first trait of a leader, possibly due to the perceptions of virtue of the "philosophically naive folk," as projected upon leaders according to a meta-analysis and resulting experiments of non-Indians according to Cokely \& Feltz (2011). Thus, non-Indian 
researchers and populations share this idea.

Leaders are not loners. They are inherently part of a social group. So it is the people of the group who determine that certain people possess leadership qualities. It is one thing to declare oneself a leader, and another when people treat you as one. Greed and dishonesty in representation are not leadership qualities. For example, the 19th Century Chief Joseph thought it best that his small tribe survive rather than ask the dwindling men and boys to die by fighting against technologically advanced settlers arriving eastward into their land. War was senseless by the late-1800s; the magnitude of settlers was not leaving. Chief Joseph knew of the population imbalance and advocated for his people, for autonomy as opposed to war. He gained respect in this decision.

Acting in concern for others, is primary, and must be in the heart of a leader. In other words "other-directedness," as discussed by Heller, Cunningham, \& Heller (2003). Responsibility emerges from group membership. According to a survey of fifteen-thousand organizations, "the more wise compassion you practice as a leader, the faster and higher you will rise in the ranks" (Hougaard, Carter, \& Hobson, 2020). Thus, there seems to be a correlation in many cultures associating leadership with trustworthiness.

Creativity is having the capacity for original thought. There is indisputable evidence that acknowledges the creativity and invention of the Native leadership depicted in these case studies (Greene, 2000; West, 2020) and of Native American people generally (Landon \& McDonald, 2013). However, individual successes in Native cultures are not so much a recognition of a person than it is representative of the capacity of the people. Thus, leadership exudes from a culture and manifests itself as a creative force in a person.

Creative thought is a hallmark quality of a modern leader (Miller, 2018). This is so, despite contemporary disagreement in business administration-that non-creative leaders themselves have tendencies to shy away from creativity in others (San Diego School of Business, 2018; Jones, 2019). This anomaly perhaps underscores the importance of innate creativity. Innate creativity allows for potential access to broader solutions of problems-creative processes and responses. If one lacks innate creativity, there is hope; some psychologists assert it can be learned, nurtured, or taught (Pringle, 2020).

Leaders have ability to use time as in action/inaction or timing; they are aware of the infinite. Timing is integral to the effectiveness of any leaders' plans. According to the acclaimed 21 Irrefutable Laws of Leadership (Maxwell, 2007), there are four-rules in timing, rephrased as follows: wrong action plus wrong time will be disastrous. Correct actions with the wrong time breeds resistance. Wrong action with the right time is a mistake. The correct action at the correct time leads to success (2007). Timing is an intuitive skill that will be needed to affect change in one's surroundings and aid the manner in which decisions have the greatest effect. Although the U.S. Air Force removed timing from its list of principles of war in 1997, the importance of timing in historical, 
low-powered warfare is not lost in that declaration (Evans, 1997). Timing of decisions, nevertheless, has broad application.

Five-practices of infinite-minded leadership suggested for current leaders were encapsulated recently in The Infinite Game (Sinek, 2019). Sinek discussed actions invoking trust, justice, study of rivalry, existential flexibility, and demonstration of courage in fulfilling long-term goals as infinite notions. However, the views most aptly representative of Native conceptualization of finite and infinite is that both resources and human experiences are temporary, and that respect for the universe, the unknowable, including a sense of spirituality, must ground one's perspective.

A humble nature is also derived from one's sense of time, and knowing how others perceive it can help leaders, too. Native treatment of time is akin to driftwood floating on river water; less authoritative and more open to the moment despite complex planning. Timing is universally associated with leadership; however, the perspective of time in Native people has been, historically, to avoid trying to control it. Seasons and times in a day are respected, yet flexibility in time can permit quick uncharacteristic response. Being subjected to the restrictive reservations can change this.

Leaders seek education via counsel and are open to acknowledge others' ideas. Fundamentally distinguished from innate sense of direction and confidence is the cognate idea that in some contexts—one might need to seek wisdom from outside of ourselves-in another, or from many sources: archives, prayer, or seeking thoughts of those lying outside the usual consciousness of the people: strangers (those disconnected to the issue). Additionally, a leader may need to target specific forms of advice within a tribe as in experienced counsel. A willingness to entertain other ideas to inform a cause of action is responsible leadership. Discretion to do this lies with the leader in situational contexts. Learning to use others' abilities and frameworks is appropriate for developing wisdom. Moreover, the skill of being a critical listener is tied to this function. After all, Native American people have maintained a strong oral traditional practice through the centuries. This tradition demands critical listening to other people when they address you, and close listening influences the continued transmission of cultural values.

Leaders are Masters of communication; can behave purposefully, or invoke others' behavior. Of course, leaders must be intelligent. Yet, not every intelligent person has the ability to explain things clearly. Leaders must not only realize the central issues at hand but need to possess the ability to explain these to people (Chatman et al., 2020). Consensus is a by-product of explaining and clarifying issues, not forcing agendas on people to get a reaction. Consensus equals an informed people, whereas manipulating agendas creates subjects or disciples-a precinct level trick, at best. Each one of these leaders had such a respect and command of many forms of communication.

As solutions do not fall from the sky, leaders will have taken the time to 
ponder about consequences. It will be from those meditations that leaders decide the most appropriate course of action. Otherwise, what you have is a clairvoyant. A clairvoyant is not concerned with outcomes, a clairvoyant simply reports what is going to happen next and does not calculate variables. Consider the unspoken consensus realized by Chief Joseph-although he desired true freedom for his people, he wanted to fight, to remain free. However, by 1885 his people were few and hungry. He had to admit-many of whom already knew-it was in everyone's best interest to settle, so the Nez Pierce would live-albeit on a reserve (Wikipedia, 2021b). Thus, having conscious contact to the pulse of the people, interpreting social movement is important as unobtrusive communication. This can be seen in Quanah Parker's case, too

Creating consensus by modeling is but one way of communicating. There is a powerful alternative: through symbols and other forms of non-verbal communications. Native sign language, use of face-painting in ceremony or combat; and the tactic of sending people to do things while others are watching. Consider the Siege of Detroit, in 1812. British Major General, Isaac Brock and Shawnee Chief, Tecumseh used spectacles. They used propaganda they allowed to be intercepted, disguising militia as regular army soldiers, and repeatedly marched the same body of Native Americans by U.S. observers to make them appear more numerous (Lossing, 1869). Using behaviors of others can have powerful effects on perception. Distractions, ruses, demonstrations are effective tools against opponents, and have been since ancient times (Tzu, 2010). These tactics are also of contemporary concern (Burke, 2018).

\section{Conclusion}

Recalling that the Iroquois Council was elevated to leadership via clan matriarchs, was this because nominees embodied the sacred consciousness of their people, above all (an innate concept)? Not enough can be stated about these matriarchs-matriarchies are abounded in Native American tribes. Their actions led the authors to notice underlying assumptions about Iroquoian clan mothers' standards, and be worth noting for context: 1) nominees by clan mother's possessed innate cultural and historical knowledge, or had sufficient cognate prostheses (archives, stories, advice) for training; 2) people knew what was expected of them in order to act in lieu of tribal desires. Nominees held the strongest of community ties and thought of themselves last. This is, in essence, maintaining the counsel of the consciousness of the people. The Iroquois' founding document Kayanerenkó wa is translated as just that: Counselor of the people (Harris \& Johnson, 2009). Capacity for leadership can be discovered in organizations today, as then (Trimble, 2020).

Beyond the scope of warfare, when it comes to studies in Native American leadership, research is scarce. However, this seems to be changing. An emerging diversity of Native American leaders continue to develop in various contexts (White, 2020). Although Indigenous people of the Western hemisphere, partic- 
ularly The United States, were the subject of this inquiry, and the Innate Cognate Leadership Typology was synthesized from remnants of this history, the typology (cluster of 5-traits) described above can be applied in vast fields: business, public service, or academia-despite heredity. One only needs to look toward Spotted Tail to remember what happens in turning away from these five-essential aspects of leadership.

By enhancing these five-traits: integrity, heightening one's awareness of time, broadening creativity, mastering many forms of communication, and seeking counsel as needed, leaders will inform many situations, contexts, and unlock many strategies. One's strength in each of the five (innate and cognate) areas will largely contribute to the effectiveness of the approach. However, more directed research on real-world applications and further historical exploration using this innate-cognate leadership typology will be informative. This typology is much simpler than known historical leadership theories. Nevertheless, practice will have to inform on its simplicity. It is our contention that the hard-earned wisdom of historical Native American leadership will serve you.

\section{Acknowledgements}

Thanks to all who helped provide motivation in our education, including the leaders within this study whose sacrifices are sometimes lost in contemporary society: we honor them.

\section{Conflicts of Interest}

The authors declare no conflicts of interest regarding the publication of this paper.

\section{References}

Alanis, Y. R. (2020). Native American Leadership in Economic Development an Exploratory Case Study. Doctoral Dissertation, Northcentral University.

Allen, P. (1986). The Sacred Hoop: Recovering the Feminine in American Indian Traditions. Beacon Press.

Anthers, B. (2008). Learning from Foxwoods: Visualizing the Mashantucket Pequot Tribal Nation. The American Indian Quarterly, 32, 204-218.

https://doi.org/10.1353/aiq.2008.0011

Azad, N., Anderson Jr., H. G., Brooks, A., Garza, O., O’Neil, C., Stutz, M., \& Sobotka, J. (2017). Leadership and Management Are One and the Same. American Journal of Pharmaceutical Education, 81, 102. https://doi.org/10.5688/ajpe816102

Beckstein, A. (2021). American Indian Leadership Might Benefit Global Leaders Working in Collectivist Contexts. In Global \& Culturally Diverse Leadership in the $21^{\text {st }}$ Century. International Leadership Association.

https://www.researchgate.net/publication/353380279

Bigorrin.org (2021). Today, Seats on the Council Are Distributed among the Six Nations as: 14 Onondaga, 10 Cayuga, 9 Oneida, 9 Mohawk, 8 Seneca, 6 Tuscarora.

Binkovitz, L. (2013, January 16). Who Were the Six Native American Chiefs in Teddy Roosevelt's Inaugural Parade? https://smithsonianmag.com 
Bryant, M. (1996). Contrasting American and Native American Views of Leadership. $A$ paper presented at the Annual Meeting of the University Council for Educational Administration, Louisville, KY, 25-27 October 1996.

Burke, S. (2018). Strategic Distraction: America, China, and Japan in the $21^{\text {st }}$ Century Competitive Space. New America.

Carlson, P., \& Crum, T. (2009). The "Battle" at Pease River and the Question of Reliable Sources in the Recapture of Cynthia Ann Parker. The Southwestern Historical Quarterly, 113, 32-52. https://www.jstor.org/stable/27794584

https://doi.org/10.1353/swh.2009.0070

Carlson, P., Cram, T., \& Murray, G. (2010). Myth, Memory, and Massacre: The Pease River Capture of Cynthia Ann Parker. In Studies in the American Southwest (p. 195). Texas Tech University Press.

Carney, V. (2001). Woman Is the Mother of All: Nanye'hi and Kitteuha: War Women of the Cherokee. In B. A. Mann (Ed.), Native American Speakers of the Eastern Woodlands: Selected Speeches and Critical Analyses (pp. 123-144). Greenwood Press.

Cash, J., \& Wolff, G. (1974). The Comanche People (pp. 9-10). Indian Tribal Series.

Chatman, J., Johnson, A., White, E., \& Bell, R. (2020). The Leader as Effective Communicator.

https://www.researchgate.net/publication/339366410 The Leader as Effective Comm unicator

Chilisa, B. (2019). Indigenous Research Methodologies. Sage.

Clow, R. (1998). The Anatomy of a Lakota Shooting: Crow Dog and Spotted Tail, 1879-1881. South Dakota History, 28, 209-227.

Clow, R. (2019). Spotted Tail: Warrior and Statesman. South Dakota Historical Society Press. https://sdhspress.com

Cokely, E. T., \& Feltz, A. (2011). Virtue in Business: Morally Better, Praiseworthy, Trustworthy, and More Satisfying. Journal of Organizational Moral Psychology, 2, 13-26. https://philpapers.org/rec/COKVIB

Cooper, T. (1988). A Time before Deception: Truth in Communication, Culture, and Ethics (p. 244). Clear Light Publishers.

Cunningham, A. (1889-1892). Ethnologic Gleanings among the Nez Perces [sic]. Robert Lee Sappington Caroline D. Carley (eds.) Research Notes volume 29. Journal of Northwest Anthropology.

Dockstader, F. (1977). Great North American Indians: Profiles in Life and Leadership. Litton Educational Publishing, Inc.

Dowd, G. (1992). Thinking and Believing: Nativism and Unity in the Ages of Pontiac and Tecumseh. American Indian Quarterly, 16, 309-335. https://doi.org/10.2307/1185795

Evans, D. (1997). Timing and Tempo. In War: A Matter of Principles. RUSI Defence Studies Series (pp. 140-145). Palgrave Macmillan. https://doi.org/10.1007/978-1-349-25956-4_15

Fee, C. (1936). Chief Joseph: The Biography of a great Indian. Wilson-Erickson.

Freeman, B., Bess, G., Candace, M., Fleming, C., \& Novins, D. (2019). Transforming through Leadership: A Qualitative Study of Successful American Indian and Alaska Native Behavioral Health Leaders. BMC Public Health, 19, Article No. 1276. https://doi.org/10.1186/s12889-019-7600-9

Gambrell, K., \& Fritz, S. (2012). Healers and Helpers, Unifying the People: A Qualitative Study of Lakota Leadership. Journal of Leadership \& Organizational Studies, 19, 315-325. 
https://digitalcommons.unl.edu/aglecfacpub/59 https://doi.org/10.1177/1548051812442749

Gelo, D. J. (1998). The Last Comanche Chief: The Life and Times of Quanah Parker. By Bill Neeley. (New York: Wiley, 1995. xii, 276 pp. Cloth, \$24.95, ISBN 0-471-11722-6. Paper, \$16.95, ISBN 0-471-16076-8). The Journal of American History, 84, 1523-1524. https://doi.org/10.2307/2568162

Goleman, D., Boyatzis, R., \& McKee, A. (2002). Primal Leadership: Realizing the Power of Emotional Intelligence.

Greene, J. (2000). Nez Perce Summer, 1877: The U.S. Army and the Nee-Me-Poo Crisis. Montana Historical Society.

Greer, C., \& Plunkett, R. (2007). Supervisory Management (11th ed., p. 261). Prentice Hall.

Guthrie, T. (2007). Good Words: Chief Joseph and the Production of Indian Speech(es), Texts, and Subjects. Ethnohistory, 54, 509-546.

https://doi.org/10.1215/00141801-2007-005

Halbert, H., \& Ball, T. (1895). The Creek War of 1813-1814. Chicago: Donohue and Henneberry; Reprint, Edited, with an Introduction and Notes by Frank L. Owsley, Jr. University of Alabama Press, 1969.

Hanson, C. (2012). Indigenous Research Methodologies. International Journal of Critical Indigenous Studies, 5, 93-95. https://doi.org/10.5204/ijcis.v5i1.97

Harris, A., \& Johnson, T. (Eds.) (2009). Haudenosaunee Guide for Educators. National Museum of the American Indian, Smithsonian Institution Washington, Smithsonian Institute.

https://americanindian.si.edu/sites/1/files/pdf/education/HaudenosauneeGuide.pdf

Harris, L., \& Wasilewski, J. (2004). Indigenous Wisdom of the People Forum: Strategies for Expanding a Web of Transnational Indigenous Interactions. Systemic Research and Behavioral Science, 21, 505-514. https://doi.org/10.1002/sres.632

Heller, C., Cunningham, B., \& Heller, H. (2003). Selecting Children's Picture Books with Positive Native American Fathers. Multi-Cultural Review, 12, 43-48.

Historynet.com (2021). Native American Indian Chiefs: List of Native American Chiefs and Leaders.

Hougaard, R., Carter, J., \& Hobson, N. (2020, December). Compassionate Leadership Is Necessary-But Not Sufficient. Harvard Business Review.

https://hbr.org/2020/12/compassionate-leadership-is-necessary-but-not-sufficient

Howard, H. (2017). Saga of Chief Joseph. Bison Classic Edition. Nebraska University Press.

Hyde, G. (1961). Spotted Tail's Folk: A History of the Brulé Sioux. University of Oklahoma Press.

Jimenez-Luque, A. (2020). Exercising Public Leadership from Below: An Empirical Research on a Native American Health Clinic Organization. Journal of Leadership Studies, 14, 74-79. https://doi.org/10.1002/jls.21687

Jones, D. (2019, November). Why Creativity Is a Powerful Leadership Tool and How to Embrace It.

Kjellström, S., Stålne, K., \& Törnblom, O. (2020). Six Ways of Understanding Leadership Development: An Exploration of Increasing Complexity. Leadership, 16, 434-460. https://doi.org/10.1177/1742715020926731

Koshhal, K., \& Guraya, S. (2016). Leaders Produce Leaders and Managers Produce Fol- 
lowers: A Systematic Review of the Desired Competencies and Standard Settings for Physicians' Leadership. Saudi Medical Journal, 37, 1061-1067.

https://www.ncbi.nlm.nih.gov

https://doi.org/10.15537/smj.2016.10.15620

Landon, R., \& McDonald, D. (Eds.) (2013). Native Americans Thought of It: Amazing Inventions and Innovations (We Thought of It) (Illustrated ed.). Annick Press.

Laxer, J. (2012). Tecumseh and Brock: The War of 1812. House of Anansi Press.

Leahy, T. (2005-2006). Beef Instead of Bayonets: Cultural Mores and the Failure of Assimilation on the Kiowa Comanche Reservation. The Chronicles of Oklahoma, 83, 496.

Lewin, K., \& Lewin, G. (Eds.) (1948). Resolving Social Conflicts: Selected Papers on Group Dynamics (1935-1946). Harper and Brothers.

Lossing, J. (1869). The Pictorial Field-Book of the War of 1812 (pp. 261-262). Harper \& Brothers.

Lowe, M., Maxson, B., Stone, S., Miller, W., Snajdr, E., \& Hanna, K. (2018). The Boolean Is Dead, Long Live the Boolean! Natural Language versus Boolean Searching in Introductory Undergraduate Instruction. College \& Research Libraries, 79, 517-534. https://doi.org/10.5860/crl.79.4.517

Maxwell, J. (2007). The 21 Irrefutable Laws of Leadership: Follow Them and People Will Follow You. Thomas Nelson.

McGowan, K. (2001). Weeping for the Lost Matriarchy. In B. Mann (Ed.), Native American Speakers of the Eastern Woodlands: Selected Speeches and Critical Analyses (pp. 53-68). Greenwood Press.

McHugh J., \& Mackowiak, P. (2014). Death in the White House: President William Henry Harrison's Atypical Pneumonia. Clinical Infectious Diseases, 59, 990-995. https://doi.org/10.1093/cid/ciu470

Miller, L. (2018, February). The Importance of Creative Leadership. https://clutch.co/hr/resources

Moses, N. (1996). Wild West Shows and the Images of American Indians: 1883-1933. University of New Mexico Press (p. 157).

Munson, T. E. (2007). Native American Leadership Theory: A Tribal Perspective. PhD Dissertation, Capella University.

National Park Service (2021). El camino real de los Tejas: The Early Caddo. https://www.nps.gov/elte/learn/historyculture/caddo-early-history.htm

Nind, M., \& Lewthwaite, S. (2020). A Conceptual-Empirical Typology of Social Science Research Methods Pedagogy. Research Papers in Education, 35, 467-487. https://doi.org/10.1080/02671522.2019.1601756

Norman Transcript (2007, May 10). Quanah Parker Made Tribe’s Transition “On His Terms".

Pringle, Z. (2020, June 9). Creativity: The Art and Science of Creativity Can Be Taught. Research Reveals New Ways to Teach Creativity to Children and Adults.

Rainer, M., Danilov, A., Irlenbusch, B., Weisel, O., \& Shalvi, S. (2018). The Honest Leader Effect-How Hierarchies Affect Honesty in Groups. Academy of Management Annual Meeting Proceedings, 2018, Article ID: 10365.

Reedy, J., Orr, R., Spicer, P. et al. (2020). Deliberative Democracy and Historical Perspectives on American Indian/Alaska Native Political Decision-Making Practices. Humanities and Social Sciences Communications, 7, Article No. 16. 


\section{https://doi.org/10.1057/s41599-020-0506-4}

Rilke, R. M., Danilov, A., Irlenbusch, B., Weisel, O., \& Shalvi, S. (2017). Contextualizing Leadership: A Typology of Global Leadership Roles. Journal of International Business Studies, 48, 552-572. https://doi.org/10.1057/s41267-016-0030-3

San Diego School of Business (2018, November 18). Uncreative: Why Leaders Dodge Creativity.

Serena, K. (2019, February 25). Chief Joseph Sought Peace with the U.S. Government through Diplomacy-But They Wouldn't Listen.

Sinek, S. (2019). The Infinite Game. Portfolio Penguin.

Sugden, J. (1986). Early Pan-Indianism; Tecumseh's Tour of the Indian Country, 1811-1812. American Indian Quarterly, 10, 273-304. https://doi.org/10.2307/1183838

Swenson, J. (2019). Bound for the Fair: Chief Joseph, Quanah Parker, and Geronimo and the 1904 St. Louis World's Fair. American Indian Quarterly, 43, 439-470. https://doi.org/10.5250/amerindiquar.43.4.0439

Trimble, J. (2020). "Being Grounded in the Ancestors and Looking Forward..."-Blending Culturally Competent Research with Indigenous Leadership Styles. Prevention Science, 21, 98-104. https://doi.org/10.1007/s11121-019-01063-9

Tzu, S. (2010). The Art of War. Capstone Publishing.

U-s-history.com (2021). Significant Native American Leaders.

Walden, A., \& West, A. (2019). American Indian Researcher Perspectives on Qualitative Inquiry about and within American Indian Communities. American Journal of Community Psychology, 64, 83-95. https://doi.org/10.1002/ajcp.12357

West, E. (2012, December). Tecumseh's Last Stand. American History.

West, E. (2020, December). Dreamweaver: Chief Joseph.

White, D. (2020, August). Native American Leadership Style Influence of Anglo Manager in Native-Owned Casino: A Phenomenological Study. PhD Dissertation, Business Administration at Northcentral University.

Wikipedia (2021a). List of Native American Leaders of the Indian Wars. https://en.wikipedia.org/wiki/List of Native American leaders

Wikipedia (2021b). Nez Pierce Chief Joseph. https://en.m.wikipedia.org/wiki/Chief Joseph

Woodward, T. (1859). Woodward's Reminiscences of the Creek, or Muskogee Indians (pp. 94-95). Barrett \& Wimbish. 


\section{Appendix A. 50 Leaders}

Singly Listed: Individuals Standing Bear, Chief Two Moons Meridas, Little Chief, Chief Buffalo Child Long Lance, Sun Chief, Illiniwek, William McIntosh, King Haglar, Sequoyah, Chief Agatha Biddle, Pontiac, Two Sticks, Black Kettle, Ely Parker, Wilma Mankiller, John Ross, Red Jacket, Ouray, Bull, Joseph Bryant, Spotted, Will Rogers, Hiawatha. Double Listed: Major Ridge, Pushmataha, Victorio, Cornplanter, American Horse, Will Chief Joseph, Mangus Coloradas, Powhatan, Blackhawk, Chief Leshi, Quanah Parker, Bigfoot, Pocahontas, Sakajawea, Santana/Satanta, Rain-in-the-Face. Thrice Listed: Gal 1, Crazy Horse, Manuelito. Red Cloud, Tecumseh, Spotted Tail, Sitting Bull, Seattle. Listed Four Times: Cochise, Geronimo. 